The Geneva Papers on Risk and Insurance, 23 (No. 87, April 1998), 247-264

\title{
Development Risks, Strict Liability, and the Insurability of Industrial Hazards
}

\author{
by Göran Skogh*
}

\section{Introduction}

The economic analysis of accident law is a success story of Law and Economics: theoretical research has increased the knowledge of efficient tort liability rules and insurance, and the results have been of practical importance in the legal development. Nonetheless, the analysis fits poorly with many serious industrial hazards of our time, such as nuclear melt-downs, widely spread chemical pollution, sickness due to additives in food, etc. One reason is that the liable party may become insolvent and/or the risk may be uninsurable. Reasons for uninsurability are potentially very large claims or great uncertainty about the accident risk. A major problem is that new risks cannot be estimated with any accuracy, either empirically or technically. Therefore, compensation and prevention are inefficient.

In this article we address the question of how industrial accidents can be prevented and victims compensated at large industrial hazards. The economic analysis of liability is extended to new areas, where uncertainty prevails and/or insurance is not available. In Section 2, we discuss the concepts of "risk" and "uncertainty". Thereafter, we examine various forms of financial risk management. In Section 3, we study diversification, i.e. the liable party reduces risk by investing in different projects, assets, or liabilities. In Section 4, we examine insurance, i.e. the liable party trades the liability to an insurer at a premium fixed ex ante. In Section 5, we examine risk-sharing, i.e. two or more parties agree to share a risk. The simplest form is a mutual guarantee to cover each other's losses. In Section 6, we examine public compensation schemes. The problem of prevention at uncertainty is

* Professor, School of Management and Economic, University of Linköping and the International Institute for Industrial Environmental Economics, Lund University. Phone +46 132815 41. fax +46132817 73, E-mail laurecon@algonet.se. 
treated in Section 7. In Section 8, we compare the various risk-handling alternatives, depending on the type of risk, firm, and size of accident loss. Final remarks follow in Section 9.

\section{Development risks}

Most current research on liability and insurance is based on the assumption that policy-holders and insurers know the probabilities of accidents, or base their decisions on subjective beliefs about probabilities, also at genuine uncertainty ${ }^{1}$. The classical distinction between predictable risk and unpredictable uncertainty made by Frank Knight (1921) is regarded as null and void in mainstream insurance literature ${ }^{2}$.

Nevertheless, we find the concepts of Knight useful, and define an actuarial risk as a contingency that can be empirically or technically estimated. The expected accident cost can be calculated, and the risk is possible to price ex ante. Actuarial risks are old risks in the sense that they have been experienced repeatedly. Examples are fire and water damage risks that may be covered by ordinary insurance policies. The information is public in the sense that insurers, as well as policyholders, know the probability of occurrence and how various safety measures and precautions reduce the risk.

Development risks, on the other hand, are new risks arising due to technological or social changes. The total lack of experience makes it impossible to foresee such risks and to make estimates regarding the probability of accidents. Any belief about the probability is, thus, arbitrary ${ }^{3}$. Consequently, accident prevention cannot be based on information about marginal conditions ${ }^{4}$. The only way to escape the accident risk is to avoid the dangerous activity itself.

An example is the production and use of asbestos before asbestosis was detected. Asbestos was regarded as a most useful product, although everyone knew that there was a possibility that it might be harmful (as with anything in life). As long as there was no specific information about the danger, no one considered stopping production. Accordingly, information was not available about how to obtain marginal reductions in the risk of incurring asbestosis. Other examples in a similar vein are risks of cancer or allergies from newly invented chemicals and new techniques. We know that a danger exists, but the uncertainty about the size of potential losses and/or their probabilities is genuine.

There is, of course, a wide range between the two extremes of actuarial risk and development risk. On the scale in-between, we define unpredictable hazards as observed

\footnotetext{
${ }^{1}$ This approach has dominated since the seminal work of Savage (1954).

${ }^{2}$ Knight's concepts, however, are accepted in institutional economics, where bounded rationality is basic, see e.g. Williamson (1985).

${ }^{3}$ Our use of the word "development risk" is close to the wording of the European Council Directive of 25 July 1985, 85/374/EEC, Art. 7 e, on product liability, which states "that the state of scientific and technical knowledge at the time the product was put into circulation was not such as to enable the existence of the defect to be discovered."

${ }^{4}$ In the standard model of tort liability - where $L$ is the constant potential loss, the probability of an accident is $p$ depending on the control $x$, and the cost of control is $w$ - the total cost of accident that the party is supposed to minimise is $L p(x)+x w$. The minimisation requires information about the marginal condition $L p^{\prime}=w$, that is, detailed information about the $p(x)$ function is assumed.
} 
dangers that are known to exist but are not possible to predict statistically. For instance, the probability of damage due to a new pesticide in agriculture may be unknown. Yet, it is known that similar substances are harmful. Precautionary measures in terms of the reduced use of the pesticide may, thus, be undertaken although the risk is not quantifiable. After an accident, or some other evidence attesting to the hazard, understanding about the adherent risk increases. However, the lack of repeated experience makes it complicated or impossible to make estimates with assurance of the probability of an accident. While the parties may have formed, certain beliefs about the risks, the confidence in their beliefs is limited ${ }^{5}$. Nevertheless, in the long run, technical investigations and repeated experience might transfer the uncertainty into a statistically predictable actuarial risk.

Although we exemplify an actuarial risk with insurance, this does not mean that insurability requires the to be risk be predictable. Anyone may bet on a risk at a fixed premium without actuarial information. Hence, statistical predictability is not a necessary prerequisite for insurance. What matters is the subjective beliefs of the parties and their attitude towards risks ${ }^{6}$.

Nevertheless, most insurers are unwilling to statistically cover unpredictable risks. It is by insuring a large number of similar risks that insurers obtain information on the actuarial relation between claims, safety devices, levels of deductibles, and costs of claim settlement. This specialisation creates an informative advantage that forms the base for profits in the industry ${ }^{7}$. It also explains why statistical predictability is regarded as fundamental by the insurance industry ${ }^{8}$. Risks that are unpredictable are very costly to insure, if they are traded at all on the market ${ }^{9}$. Insurers are reluctant to provide coverage against events where the probability of its occurrence is ambiguous, either because of limited statistical data and/or the different views of experts regarding the underlying causality ${ }^{10}$. Losses also need to be well- defined, limited, and possible to estimate.

All in all, insurers normally require that covered risks are actuarial. This motivates us to simplify and use the concepts insurable risk and actuarial risk as synonyms.

\section{Diversification}

\section{A widely-held firm}

Below, we examine a "unilateral case", i.e. a firm is strictly liable for an industrial accident. The victim's potential contribution to the accident risk is neglected. The accident is tortorial or "environmental" in the sense that there is no contractual relation between

${ }^{5}$ For a formal treatment of the concept "confidence", see Hirschleifer \& Riley (1979).

${ }^{6}$ See Savage (1954), and Gördenfors \& Sahlin (1988).

${ }^{7}$ Skogh ( 1991).

${ }^{8}$ Berliner (1982).

${ }^{9}$ The impact of unpredictability on the price of insurance is exemplified in the insurance of the first jet- liners, see Borch (1990, Chap. 7). The hull insurance premium was first set to 8 percent of the hull's value. After some experience was gained, the premium was gradually reduced to less than 1 percent of the hull value. Although considerable information was available at the outset, such as information about personal transportation by propeller planes and the accident rates of military jets, this great reduction in price took place at a later date. The insurance premium was, thus, very high to begin with even though some information was available.

${ }^{10}$ Hogarth \& Kunreuther (1992). 
the industry and the potential victim. Moreover, the identity of the injurer is not questioned. Our interest focuses on the financial risk management of the liable firm.

In the economic literature on tort law, it is assumed that risk-averse parties insure. However, diversification may be a cheaper alternative for the corporate firm. We distinguish between a closely-held firm, i.e. a firm with no access to financial markets, and a widely-held firm, i.e. a firm with access to financial markets. We will first study payable accidents, i.e. the largest possible claim is equal to, or less than, the value of the firm. Later, we will study unpayable accidents, i.e. the accident costs are higher than the value of the firm.

Diversification can be undertaken internally in a firm or externally via financial markets. An example of internal diversification is a ship owner who sends several small ships instead of one large one or a farmer who plants various crops. Internal diversification is normally costly, primarily due to the loss of economies of scale. Therefore, a cheaper option to the widely-held firm may be to utilise economies and diversify through the holding of a mixed portfolio of assets and liabilities.

Transactions on the financial market are usually made at low costs. We will disregard these costs and assume that the transactions are costless. First, we will examine the case where the potential accident is payable. Zero collection cost is assumed. The liable firm, thus, pays damages in case of an accident. Finally, the owner of the firm is risk-averse.

Another general result of the portfolio theory is that the best a widely-held corporation can do is to maximise expected profits ${ }^{11}$. This is also true if the stock owners are risk-averse. For instance, if there is a risk of fire, explosion, or third-party liability that occurs independently in different firms, the shareholders may diversify by mixed portfolios. Systemic risks, on the other hand, cannot be diversified within the firm, or by the stock-holders. An example may be liability for accident caused by chemicals used in most industries. The best choice available for the risk-adverse stockholder, therefore, is to combine risky and secure assets in a proportion maximising utility ${ }^{12}$.

A further result is that all public information on the expected value of assets and liabilities will be included in the price of the stock. Insurable risks are usually based on public information. Insurable liability will, therefore, reduce the value of the equity by the expected accident cost. Similarly, if a firm takes preventive measures that reduce expected accident costs, the value of the firm will be increased by as much as the gain. The best choice of the firm, therefore, is to minimise the expected costs of accident and accident prevention. The financial market, thus, solves the prevention problem in an efficient way non-utility due to risk-aversion is diversified and the costs and benefits of accident prevention for an actuarial risk are reflected in the value of the firm. This outcome is equivalent to the case where the risk-averse liable party fully insures, and the insurer is fully informed about the impact of preventive measures at zero administrative costs ${ }^{13}$. Hence, in a perfect world with known probabilities and no transaction costs, diversification and insurance provide the same efficient result.

${ }^{11}$ For an introduction to portfolio theory, see Elton \& Gruber (1981)

${ }^{12}$ The discussion here neglects the control aspect in the firm. To control the firm, an owner may need a large part of the equity. A single owner with enough shares to contol the firm may incur large losses. Hence, risk-aversion cannot be neglected.

${ }^{13}$ Shavell $(1979$, ch 9-10). 
Consider a firm that is liable for a new hazard of which the expected outcome cannot be estimated. The existence of the risk may be public knowledge, but it is statistically unpredictable. It is well-known that uncertainty does not prevent trade in financial markets. Traders bet continuously on highly uncertain projects. Indeed, the large fluctuations in stock prices is an indication of the limited confidence present in the value of the assets traded.

Liability of such industrial hazards will presumably reduce the value of the firm; however, it is uncertain by how much because it is not possible to price the risk properly. Unsubstantiated news and rumours in the media may precipitate large reactions on the market. Precautions will also be uncertain and poorly priced. Some risks may not be considered at all, while others may cause inefficient over-protection.

Liability for development risks that are not at all foreseen has presumably no impact on stock prices. When information becomes available, e.g. an accident occurs, it will reduce the value of the firm by the amount of the accident damage, and with discounted future expected accident costs. A secondary effect of an accident of a new type is that it creates an awareness that reduces stock prices for all firms facing similar risks. The expected accident costs will, thus, be spread to the stock owners. Hence, liability for pure development risks causes windfall losses that can be regarded as a lump sum tax on stocks.

Diversification via financial markets, therefore, appears to be efficient relative to the level of uncertainty - losses are diversified and available information used for prevention. Liability is limited, however, to the value of the corporate firm. In the case of losses larger than the limit set by bankruptcy, an economic incentive to take precautions or to diversify is not present ${ }^{14}$.

\section{A closely-held firm}

We turn to the case where the liable party is a closely-held firm with no access to the financial market. It may be a stock company with few owners, a partnership, or a nonprofit firm. The loss is payable, that is, the largest claim equals the assets of the firm (or of the assets of the owners in a firm with unlimited liability).

First, we consider an actuarial, insurable risk. The risk-averse owner may diversify the risk and/or insure it. However, insurance is costly, as is diversification ${ }^{15}$. Most production benefits from economies of scale and the loading costs of insurance are important. Nevertheless, given that the accident risk is relatively small and the loading charge of insurance not too high and, thereby, the premium relatively low, the firm will insure the risk and utilise economies. The insurer will use available information to limit moral hazard by means of the stated conditions in the policy, deductibles, and bonuses.

Now, assume the case of a development risk or an unpredictable hazard. It may be known that production could be harmful. The damage (if any) may become evident in the future. Insurance is not available. The producer may take certain arbitrary actions according to his subjective beliefs about the danger. A risk-averse producer will take

${ }^{14}$ We assume that the size of the firm is given. However, liability may have an impact on industry structure. Liability could be reduced by organising risky production in firms with small assets. This problem will not be treated here.

${ }^{15}$ This is common with administrative loadings of 20-40 percent of insurance premiums. 
additional precautions. Diversification may be carried out by mixing inputs or processes, and by taking precautions through the careful handling of potentially dangerous goods. There is no reason to believe, however, that the precautions and the diversification will be efficient. A strongly risk-averse firm may simply leave the business, or refuse to put into use inputs or methods that may later prove to be harmless, while others may completely neglect the prospective danger.

\section{Insurance}

The traditional analysis of liability and insurance is applicable in cases where the closely-held firm is faced with a payable accident. Insurance demand by widely-held corporations, on the other hand, is not easily explained by risk-aversion and pooling. As has been noted, the best the widely-held firm can do is to maximise profit and diversify risks via the financial market ${ }^{16}$. Nevertheless, property and liability of corporate firms are usually insured. Presumably, the reason is the joint offering of risk reduction and other services. Insurance may, for instance, be motivated by low-cost claims administration services provided by insurers, assistance by insurers in assessing the value of safety and maintenance projects, and a reduction in the firm's expected tax liability ${ }^{17}$. Risk may also be transacted to insurers to reduce transaction costs in trade ${ }^{18}$.

More important here is that insurance serves as a guarantee in case of unpayable accidents. In a corporate firm with limited liability, the capacity to cover accident costs may be insufficient and the incentive to prevent losses diluted. Therefore, public authorities or parties who may be harmed require collateral or a guarantee. Indeed, insurance is often a mandatory requirement for permission to run a business, transport goods, drive a car, employ personnel, issue bonds, etc. ${ }^{19}$ Insurance is usually also a requirement at strict industrial liability.

In order to obtain a comparative advantage as risk-carrier, a guarantor must have: (i) enough assets to cover potential claims; and (ii) the capacity to monitor the liable party ${ }^{20}$.

${ }^{16}$ In the risk management literature, it is often argued that large profit-maximizing firms should self-insure losses in order to avoid the loading costs of insurance, see Smith and Warner (1979), Mayers and Smith (1981, 1982, 1987), and Main (1982, 1983). Individuals in frictionless capital markets would adjust their portfolios so that there would be no demand for a resource-consuming insurance industry. Thus, insurers have no obvious comparative advantage over corporate firms in diversifying risks.

${ }^{17}$ Mayers and Smith (1987).

18 Skogh (1989).

${ }_{19}$ Benson and Smith (1976) first noticed bond covenants requiring insurance in corporate firms. Their explanation was the one presented here, the insurance industry has a comparative advantage in dealing with property and liability risks, it is beneficial to transfer such risk to the insurance industry. Contracts may be simplified by transferring insurable risk to an insurer specialised in the risks.

${ }^{20}$ Skogh (1991 and 1997). Note that the argument for a guarantee is similar to the argument for vicarious liability in tort-law, see Sykes (1984) and Shavell (1986) - that is, a "judgment-proof" problem arises when a party that has become legally liable is unable to fully pay the claim. Someone else - for instance, an employer - may then be held vicariously liable. This situation may be efficiencyincreasing because the employer is able to observe the employee continuously and has the power to reward or dismiss the employee. In like manner, parents are often liable for damages caused by their children. Similarly, professional associations and branch organizations with the power to control membership may be willing to guarantee the services of their members. 
Examples of guarantors are banks, relatives, and business partners who are economically or socially able to control the injurer. The guarantor might also be an insurer. Insurers specialise in specific risks such as fire, health, etc. and normally cover only such losses. Insurance is, therefore, a complement to other guarantees.

In a "perfect" world in which the insurer knows the marginal impact of the controls taken by the injurer, the insurer can steer the policyholder's behaviour toward optimal care by stipulating conditions in the policy and by varying premiums. Therefore, by monitoring the injurer, insurance can contribute to efficiency also at unpayable accidents, even though knowledge and monitoring are imperfect. A serious shortcoming, of course, is that only insurable accidents are covered.

Potential victims can protect themselves to a certain extent through first-party health and disability insurance, pension schemes, and life insurance. Health treatment and income losses due to cancer, allergies, and many other diseases caused by new products and techniques are covered by these insurances. A reason why it is possible to insure development risks through first-party insurance is the law of large numbers, that is, pension and life expectancy can be estimated well enough because the cause and variations of sickness, disability, and better health are not fully correlated. First-party property insurance also protects victims when strict liability is not in force. Property insurance covers most accidental risks and industrial hazards, but may exclude potentially very large claims, such as nuclear accidents and natural disasters. Damage that is gradual and nonaccidental is also typically excluded. On the other hand, personal damage is to some extent covered by health, disability, and pension schemes.

A shortcoming of first-party insurance, of course, is the absence of the injurer's incentive to take care. Note, however, that at development risks and unpredictable hazards, only arbitrary prevention is possible at the outset.

\section{Mutual risk-sharing}

\section{Trade among equals}

Insurance, as defined above, requires that the pricing is undertaken before the occurrence of the insured event. An agreement to mutually share each other's losses does not necessarily require any pre-payment. Therefore, risk-sharing requires less information than insurance does. In other words, a group of risk-averse individuals can benenit from sharing accident costs, although the probability of an accident is statistically unpredictable. However, a presumption is that the expected risk is regarded as the same for all ${ }^{21}$.

The simplest form of risk-sharing is a mutual guarantee, where the pool members promise to cover each other's losses. The risk of each member is, thereby, transferred to a

${ }^{21}$ The logic is as follows: assume that there is a pool of $N$ individuals faced with the same (but unknown) probability of losing the amount $L$. First, regard the case where only one accident occurs in the group. The probability that a certain individual is hit is, thus, $1 / N$. Each risk-averse individual benefits from risk-sharing because she prefers a certain cost $L / N$ to the probability of $\operatorname{losing} L$ with the probability $1 / \mathrm{N}$. The procedure can be repeated for two or more accidents, various probabilities, and sizes of the loss. The individuals gain from sharing equally, except for the cases where there is no accident or all are struck by an accident. Hence, equal sharing is preferred, independent of the probability and the size of the accident, see Skogh[1996]. 
pool with more or less diversified risks. Risk-sharing requires, however, that the parties in the pool accept and trust the presumption that they are equal, that is, that all face the same risk (although they cannot estimate it statistically), and that moral hazard and adverse selection can be controlled. Members in the same business may have the ability to control each other. They also have a common interest to obtain information, and to employ risk reduction measures ${ }^{22}$, that is, the pool has a stronger incentive than the individual to undertake research.

A pool must also be large enough to efficiently diversify risks. Groups of equals tend to be small, however, and as soon as differences in the group are revealed, the pool may be split. Groups of individuals that have long-term relationships, such as families, guilds, and other societies, may be able to exert control relatively easily, and thus trust one another. They also face similar risks. Taken together, this explains risk-sharing in such groups. Throughout history, there has been mutual aid for fire, death, disease, disability, and for the loss of cargo or ships.

Today, we observe mutual risk-sharing in joint ventures and in the collective ownership of risky enterprises. Contemporary insurance companies often combine insurance and mutual pooling. Many insurance companies are mutuals ${ }^{23} 24$. Generally, mutual sharing appears to be prior to insurance that may develop at a later stage when actuarial information is available. A first step towards insurance may be the introduction of pre-payments in a mutual pool. Pre-payment may reduce distrust among pool members. Pre-payment also evens out costs over periods of time. If the pool is large enough to spread the risks, the fund large enough to even out payments over time, and actuarial information is available, the premium can be set close to the expected accident costs plus administrative costs. A modern, large mutual pool with diversified risks may charge premiums and offer no residual rights or place obligations on the policyholders. In practice, such firms are insurers according to our definition.

\section{New industrial hazards}

A closely-held firm faced with unpredictable hazards may mutually share the risks with similar firms in the absence of cheap internal diversification. By "similar", we refer to risks of the same type and dimension, and to a common understanding of prevention and control of moral hazards. The associations of farmers and professionals are just a few of many that mutually protect members, among other things. The reason for the mutual sharing may be risk-aversion for payable accidents and guarantee in relation to unpayable accidents.

A problem with risk-sharing in professional groups and among farmers, of course, are correlated risks that cannot be diversified. For instance, the fact that farmers all depend on

22 These differences between mutual risk-sharing and insurance have been neglected in the theoretical literature, which usually makes no distinction between pooling and insurance.

23 Stock companies selling insurance at a fixed premium developed during the industrial revolution hand-in-hand with the actuarial science (Bucht, 1936).

${ }^{24}$ In the most advanced commercial centers insurers bet on unpredictable risks, such as the merchants did in Florence and Genoa during the Middle Ages and in Lloydîs coffee shop in London during the eighteenth century. Note that through experience these ancient marine insurers were rather informed about the risks they covered. 
rain means that they cannot protect each other against drought. Another complication may be anti-competitive cartelisation. Risk-sharing protection may be the glue that knits the members together.

A widely-held firm has no incentive to insure or to diversify by risk-sharing as long as costless and far-reaching diversification is available via financial markets. Insurable risks are normally insured, however, because of the joint benefit of risk exposure, services, and guarantee. Risk-sharing is important at unpredictable hazards that are not insurable but require guarantee. Prerequisites for the risk-sharing of new industrial hazards are (i) that there exists a group of firms in the industry with similar risks, (ii) that a common pool exists, or can be established without too high transactions costs, and (iii) that the pool is able to control moral hazard and adverse selection ${ }^{25}$. These preconditions, of course, are not always fulfilled. However, there are interesting examples.

In 1967, a 120.000 ton oil spill polluted the British Channel after the Torrey Canyon accident. An oil spill of that size, polluting the sea and several nations had never occurred before. Coastal nations agreed to apply strict tanker owner liability, and only accept oil tankers that insured or guaranteed in their waters ${ }^{26}$. It was possible to establish the convention because the states had a common interest in covering clean-up costs, and because the convention was enforceable due to the power to exclude tankers from the harbours.

The strict liability rule made the tanker owners responsible for a new risk that was similar in all overseas oil shipping. The threat of potential liability and of not being accepted in the harbours gave an incentive to the oil traders to search for guarantees. Insurance was not available. However, marine "Compensation and Indemnity Clubs" existed and shared the potential losses. Once a member of the pool, the jointly liable tank owners became interested in regulating safety, an interest shared with the coastal states ${ }^{27}$. To increase the capacity to cover clean-up costs, a fund based on fees paid upon delivery in the harbours was also included in the convention. Nonetheless, such coverage is insufficient for accidents with claims the size of the Exxon Valdez care. Liability is, thus, still limited. One way to increase liability in such cases would be to increase the required guarantee. Another would be higher fees to the fund for future clean-ups ${ }^{28}$.

Another industry where mutual guarantees may be used more extensively is nuclear power. An international convention on the strict liability of nuclear power plant owners was signed in Paris in 1960 . The liability was combined with mandatory insurance, risksharing, or financial guarantee. Atomic pools, set up by national insurers, insure and share property and liability. Damage to the power plants may be insured. Third-party liability may also be covered, but usually to a limit set by what is supposed to be insurable. For instance, plants in Sweden are covered up to around $\$ 1.5$ billion by property insurance, while the third-party liability is limited to around $\$ 300$ million. Risk-sharing agreements

${ }^{25}$ The formation of such pools may, of course, be realised through the assistance of insurance companies.

${ }^{26}$ The distinction between insurance and risk-sharing is usually not made in the literature. Many risk-sharing organisations are, thus, called "insurance".

${ }^{27}$ Bongerts \& Bièvre (1987).

${ }^{28}$ Criminal sanctions have also been discussed but will not be treated here. 
between the signatory states, and public coverage by the Swedish state cover third-party losses up to $\$ 500$ million. The picture is the same in other signatory states. Hence, thirdparty liability is strongly limited, although the nuclear industry is strictly liable.

One way to increase liability at very large accidents is to require risk-sharing within the nuclear industry. According to the Ferguson-Anderson Act of 1988, mandatory risksharing exists in the U.S., covering third-party liability up to $\$ 9$ billion. Faure and Skogh (1992) have outlined a hypothetical European risk-sharing agreement covering nuclear power third-party liability one hundred times larger than today that would make compensations possible also for very large accidents and would create a joint interest in the industry for mutual control. However, the solution requires agreements by states and by plant owners that are unequal in many respects. Thus, a more realistic possibility might be risk-sharing by plant owners in states with similar plants ${ }^{29}$.

The doctrine of "joint-and-several" liability, where producers, creditors, suppliers, and other stakeholders are jointly liable, has been applied and questioned for several reasons in relation to polluted land in the US ${ }^{30}$. Note that the mutual risk-sharing examined here is a type of joint-and-several horizontal liability among firms in the same business, instead of vertical liability in the same chain of production. Mutual risk-sharing differs from suggested joint stakeholder liability in several important respects. First, by including many similar producers in the pool, the joint assets become relatively large. Second, diversification prevails in a mutual pool but not between stakeholders from the same firm. Third, pricing is not necessary in a mutual pool. If, on the other hand, a creditor and a supplier may be held liable for the producer's accident, they must calculate a price for the risk imposed, which may be a more or less impossible task. Fourth, the mutual is set up by the industry specialised in the business. Hence, the pool has a common interest and posesses competency regarding prevention ${ }^{31}$. That may explain why mutuals are set up freely when extensive guarantees are required.

\section{Public risk-sharing}

It is often argued that the public should cover major catastrophes and large unforeseen losses. There are several reasons why states administer mandatory risk-sharing, and citizens cover losses by taxes. One reason is lack of trust in private risk-sharing agreements. The coercive power of the State, and the public organisation (or supervision) of the pool, may be necessary for its credibility ${ }^{32}$. Adverse selection may also be mitigated by the State's power to force the citizens into the common pool. Economies in the collection of fees may also exist. A further reason for public risk-sharing is that the

${ }^{29}$ It is sometimes argued that insurance of nuclear accidents and similar catastrophes is not available because the insurance market cannot handle the potentially very large losses. The international re-insurance markets, together with the international financial markets, are large enough to diversify huge losses. Thus, the statement does not seem to be fully correct. Insurance is unavailable because of the highly limited information on the unexperienced risks. In the future, it may be possible to trade "risk participation shares" on the financial markets, as suggested by Turan and Zweifel (1993), which would diversify the risk more or less completely.

${ }^{30}$ Boyd and Ingberman (1996), and Tietenberg (1989).

31 A problem with industry-wide pools may be anti-competitive actions.

32 Hägg (1994). 
national pool is large. Interdependent and/or very large accidents are social risks in the sense that they can (at best) be diversified nation-wide or internationally.

Uncertainty about the risks may also be the reason for public risk-sharing. Hazards that are unpredictable, as well as completely unforeseen risks, may be beneficially shared collectively by all members of society. Man may foresee that the unforeseeable might occur, although the uncertainty about what will happen may be genuine. Agreements on the sharing of losses "no matter what happens" are open, however, to interpretations and conflicts ex post and, thus, may not be trusted. That may explain why agreements about mutual aid primarily exist within families, clans, and societies with strong internal control and trust. Also, on a national and international level there are explicit or implicit commitments to compensate victims of unforeseen events. The interpretation of the committment of aid and charity may be made ex post by a national parliament or by international organisations like the UN.

The idea that the community shall cover losses not only of a very large nature but also illness and disability has a long history. The Welfare State is the modern symbol of this tradition ${ }^{33}$. Today, however, many states have introduced private, or semi-private, insurance systems with a closer connection between premiums and benefits. A common argument put forth in favour of these reforms is public budget deficits. In addition, we may add the uncertainty argument: earlier, when actuarial information on individual risks was absent, public risk-sharing was a rational choice. Now, the presence of actuarial information makes a more extensive use of private insurance possible ${ }^{34} 35$.

Meanwhile, new techniques and industrial hazards place new demands on the states because catastrophes due to industrial processes, chemicals, drugs, etc. are not covered by insurance. However, new, potentially very large accidents require international diversification, but insurance and re-insurance are not available for these risks. It is, thus, a natural development to seek extended international risk-sharing conventions. However, an obstacle is that voluntary risk-sharing requires that the parties face similar risks and that they trust one another. In some instances, states may be unable to agree.

Note, however, that nations have been able to agree on making industries liable for hazards, such as oil and nuclear accidents, together with requirements of credible

${ }^{33}$ In the famous book, "A Theory of Justice", John Rawls (1971) presents the "difference principle", stating that the State shall redistribute income in favour of the worst-off. The principle is based on the idea of a social contract in a hypothetical "veil of ignorance", that is, a situation where the individuals do not know their specific risks or which preferences they will have in the future. In such genuine uncertainty, the solution is straightforward - the individuals accept equal sharing.

${ }^{34}$ In fact, the evolution of fire-insurance followed a similar pattern: many European communities organised for centuries collective sharing of losses in the event of fire. Private fire mutuals, and later insurers, took over during the nineteenth century when actuarial information became available (Bucht, 1936).

${ }^{35}$ It is interesting to note that the fear of meltdowns in nuclear power plants has much in common with the fear of town fires several hundred years ago. Towns burned down with catastrophic consequences. The risks were not insured, but to some extent the losses were covered by risk-sharing agreements, and by charity. Later, the sharing developed, and as the actuarial science grew, property and personal losses could be insured. Similarly, at a meltdown some costs will be covered by private first-party insurance and through international compensation plans. The remaining, potentially very large losses will be left to random victimisation and charity. International risk-sharing may improve the situation. When more information on the risks is available, insurance may be possible. 
guarantees. Hence, there may be room for international conventions on industrial liability, including mandatory guarantees, that is, in practice international risk-sharing by industry. Examples to be mentioned in this area are catastrophes, such as dam breaks, the mad cow and similar diseases, chemical accidents, and natural disasters.

\section{Strict liability at uncertainty}

The main argument in favour of strict industrial liability is that the injuring firm controls the activity that may cause an accident. If the injurer knows that he must cover accident costs, it has an incentive to prevent accidents efficiently. This argument is based on the assumptions that the injuring firm has access to non-public decentralised information and that the manager of the firm is able to give and enforce orders.

The assumptions about control and access to decentralised information in the firm are certainly realistic in many real world situations -- it is usually the manager of the firm who knows and controls the business. Public authorities or courts have inferior information about daily practice and the "due care" taken in a single firm. However, this is true for the most part for old and predictable "business risks".

New industrial risks are different, however. Normally, a firm has received no private information about development risks. It may have information about unpredictable hazards, but that information is typically of public interest. As soon as evidence about the danger of an activity, process, or substance appears, it is of common interest to spread the information. A firm may, of course, have a vested interest to keep the information private, but there is usually a duty to disclose information about hazards. The duty may be enforced both through criminal and civil liability. Hence, information about unpredictable risks is usually public in nature.

The lack of private information about development risks and unpredictable hazards weakens the argument for strict liability. It may be argued that strict liability for development risks is motivated anyway, because liability creates an incentive to collect information and undertake research. This may be true in a research intensive industry. However, the incentive will be at an optimal degree only if the firm controls the entire market. Otherwise, additional public research is motivated because the information pertains to the common interest. Private investigations aimed toward their own gain cause under-investments from a social point of view. Indeed, this is the standard argument for publicly financed research.

Nonetheless, there is some common knowledge about new and unforeseen accidents. We know that anything may be ultimately dangerous and that some activities appear to be more risky than others. A way to reduce risks is simply to avoid certain activities or substances. A dilemma, of course, is that the potential benefits will not actualise. An example are gene techniques, which have many very beneficent applications, yet they may also be extremely hazardous, although we may be uncertain about the areas in which the hazard may lie. Yet, the introduction of new techniques or products is often postponed until preliminary information on possible effects is obtained. For instance, experiments and tests are required before new drugs are released. However, experiments are costly and the delay may limit the use of products that are valuable. Furthermore, experiments 
outside the laboratories may be necessary in order to assure newer and safer products. Other ex ante regulations, such as restrictions on loading, the production method, storage, pollution standard, licensing, etc., are also decided at uncertainty. The regulations have uncertain benefits in relation to the costs, but are, nevertheless, widely used.

All in all, strict liability is a dull instrument at development risks and unpredictable hazards. Any prevention that can be achieved is based mainly on public safety regulation and less on private, decentralised information. Furthermore, strict liability may increase risk exposure to uninsurable risks, which is the case, for instance, if the liable party is a closely-held firm and the victim is a widely-held, diversified firm or many consumers, each with small claims. The fear of ruin is a non utility in itself and may result in inadequate behaviour. For instance, what could a farmer using pesticides do in addition to what is publicly known? Not very much. Everyone knows that pesticides should be handled, used, and stored with care, and precautions are described in safety regulations, e.g. by instructions printed on the bags. The reasonable due care to be taken by the farmer is to use permissible pesticides and follow instructions. This furnishes an argument in favour of negligence at development risks. If a negligence rule prevails and the farmer is careless in not following issued instructions or by not disclosing information, he is negligent. To avoid damage, therefore, the farmer will undertake the required precautions ${ }^{36}$. Strict liability has no comparative advantage relative to negligence, as long as the understanding of what is reasonable "due care" is public ${ }^{37}$.

\section{The management of accident costs}

\section{a. The closely-held firm with payable accidents}

We can now summarise the coverage of accident costs for various types of accidents starting with the closely-held firm with a payable accident (Column 1, Table 1). First, we study an actuarial risk, noted by $\mathrm{A}$. The risk-averse owner may diversify and/or insure the risk. We expect the firm to insure because of economies of scale and scope (Row 4). Insurance is also purchased because the insurer provides various services to the firm (Row 5). The insurer will use available information to control moral hazard.

The accident damages are divided into "payable" and "unpayable", that is: (i) damages smaller, or equal, to the assets of the firm, and (ii) damages higher than the available assets. The firms are divided into: (iii) closely-held firms, i.e. firms without access to the financial markets, and (iv) widely-held firms, i.e. firms with access to financial markets. The risks are: a. A, actuarial risks that are insurable. $A_{m}$ indicates that coverage is mandatory. Here, insurance serves as a guarantee; $b . H$, unpredictable hazards; $c . D$, development risks; and $d$. $N$, residual risks that do not result in liability.

For unpredictable hazards ( $\mathrm{H}$ in Table 1$)$, there no insurance is available. Some diversification may be carried out internally by mixing inputs or processes (Row 1 , Column 1). The cost will be in terms of economies lost. The risk may also be mutually

${ }^{36}$ For a discussion on the comparative advantages of decentralised liability and administrative regulation, see Skogh (1982) and Shavell (1989, ch 12).

${ }^{37}$ At a negligence rule, the injurer will only pay if the behaviour is regarded as careless. Injurers will normally avoid careless behaviour in order to avoid losses. Hence, the victim will carry the loss. 
Table 1: Coverage of losses

\begin{tabular}{|c|c|c|c|c|c|}
\hline \multirow{2}{*}{\multicolumn{3}{|c|}{$\begin{array}{l}\text { Accident } \\
\text { Firm }\end{array}$}} & \multicolumn{2}{|c|}{ Payable } & \multirow{3}{*}{$\begin{array}{c}\text { Unpayable } \\
\text { All firms } \\
3\end{array}$} \\
\hline & & & Closely-held & Widely-held & \\
\hline \multirow{3}{*}{ Diversification } & \multirow{3}{*}{$\begin{array}{l}\text { Internal } \\
\text { External }\end{array}$} & \multirow[b]{3}{*}{2} & 1 & 2 & \\
\hline & & & $\mathrm{H}$ & & \\
\hline & & & & $\mathrm{D}, \mathrm{H}$ & \\
\hline \multicolumn{2}{|c|}{ Mutual risk-sharing } & 3 & $\mathrm{H}$ & & $\mathbf{H}_{\mathrm{m}}$ \\
\hline \multirow{3}{*}{$\begin{array}{l}\text { Liability } \\
\text { in- } \\
\text { surance }\end{array}$} & \multirow{3}{*}{\multicolumn{2}{|c|}{$\begin{array}{l}\text { Risk-aversion } \\
\text { Services } \\
\text { Guarantee }\end{array}$}} & A & & \\
\hline & & & A & A & \\
\hline & & & & & $A_{m}$ \\
\hline \multirow{3}{*}{$\begin{array}{l}\text { Victims } \\
\text { and } \\
\text { the public }\end{array}$} & \multirow{3}{*}{$\begin{array}{l}\text { First-party ins. } \\
\text { Public sharing } \\
\text { Random }\end{array}$} & 7 & $\mathrm{D}, \mathrm{N}$ & $\mathrm{N}$ & $\mathrm{D}, \mathrm{N}$ \\
\hline & & 8 & $\mathrm{D}, \mathrm{N}$ & $\mathrm{N}$ & $\mathrm{D}, \mathrm{N}$ \\
\hline & & 9 & $\mathrm{~N}$ & $\mathrm{~N}$ & $\mathrm{~N}$ \\
\hline
\end{tabular}

shared (Row 3 ) by firms within the same industry. An obstacle may be that diversification requires the risks to be independent. Accidents taking place in one firm but not in others will be diversified, but industry-wide hazards will not be. All in all, the diversification taken by the strictly liable firm will be limited and costly, and the preventative measures will be more or less arbitrary according to the degree of risk-aversion and subjective beliefs about the risks and precautions.

A completely unforeseen development risk, D in Table 1, can possibly, to some minor extent, be reduced through diversification and by taking general precautions. However, the absence of knowledge limits the ability to act - whatever is undertaken may be inadequate. Because of the absence of efficient private prevention, development risks might be only covered by first-party insurance ( Row 7, Column 1$)$ or by public sharing and welfare plans $($ Row 8$)$. The final alternative is random victimisation (Row 9). Precautions and preventive actions motivated under such uncertain circumstances may be accomplished through public safety regulation, enforced by due care (negligence) standard, administrative sanctions, and/or criminal sanctions. ${ }^{38}$

Thus far, we have assumed that a liable party pays damages. Limits to liability have been due to corporate law or to the limited assets of the injurer. In reality, there are many reasons why a liable party does not carry accident costs. First, the injurer, or the victim, may not be identified. Second, it may not be possible to make the injurer liable according disclosed.

${ }^{38}$ Criminal sanctions may be appropriate when, for instance, information on major hazards is not 
to existing laws. This may be the case if evidence is unsatisfactory, or if the injurer is an international corporation from which damages cannot be collected. Third, the liability may only be partial in that it does not include certain costs, such as "pain and suffering", or good-will.

Whatever the reason for no liability ( $\mathrm{N}$ in Table 1 ), the result is inefficient prevention and random victimisation. Prevention can, therefore, be undertaken mainly through public safety regulations and the costs spread through first-party insurance or public risk-sharing (Rows 7-8 in Column 1).

\section{b. Widely-held firm with payable accidents}

Firms with access to financial markets and facing payable accidents are presented in Column 2, Table 1. Actuarial risks, A, will presumably be insured (Row 5, Column 2). Risk-aversion alone does not explain insurance, but it is a joint product of insurance (Row 4, Column 2).

Unpredictable hazards, $\mathrm{H}$, will preferably be diversified externally (Row 2, Column 2). Existing, but uncertain, information will have some impact on stock prices and on prevention. The best choice of a widely-held corporate firm is to maximise expected profit, which includes utilisation of economies and efficient accident prevention. Prevention will influence the value of the firm, which creates an incentive to invest in care.

Development risks, D, may be diversified externally (Row 2, Column 2), but not prevented. When development risks are realised, strict liability will cause windfall losses in industry.

For accidents where there is no liability, $\mathrm{N}$ will, by definition, not be covered by the injuring firm. Hence, it must be covered by first-party insurance, public sharing, or randomly by victims (Rows 7-9).

\section{c. Unpayable losses}

For large accidents, there is no liability over the limit set by available assets of the liable party, and thus, there are inefficient incentives to take precautions. This is true, independent of the firm type (Column 3, Table 1) ${ }^{39}$. Insurance is often required to guarantee payment of insurable risks, $\mathrm{A}_{\mathrm{m}}$ (Row 6, Column 3), where the index $\mathrm{m}$ stands for "mandatory" 40 . Mandatory mutual risk-sharing may be possible for such unpredictable hazards as, for instance, in the oil pollution case, $\mathrm{H}_{\mathrm{m}}$ (Row 3). Development risks that are unforeseen can hardly be mutually covered by industry - the hazard needs to be specified, at least to some extent. Losses due to development risks must, therefore, be covered through public risk-sharing or first-party insurance, given that random victimisation is to assets.

${ }^{39}$ Indeed, a producer may escape liability by organising risky production in firms with small

40) Benson and Smith (1976) first noticed bond covenants requiring insurance in corporate firms. Their explanation was the one presented here, i.e. in order to certify the credit, the bondholders require a guarantee not to be liable for losses larger than the value of the firm. Moreover, as the insurance industry has the comparative advantage in dealing with property and liability risks, it is beneficial to transfer such risk to the insurance industry. 
be avoided. The same is true for accidents where, for various reasons, there is no liability, N (Rows 7-9).

\section{Conclusion}

The traditional Law and Economics analysis of accident law assumes actuarial risks, and accidents small enough to be covered by the assets of the liable party. Risk-averse parties are supposed to be able to purchase insurance. From Table 1, we see that the theory covers only a part of all accidents (Row 4, Column 3) and, indeed, neglects large and serious industrial risks.

Hence, there is much research to be done. One neglected field is insurance as guarantee ${ }^{41}$. A related field is the relation between strict liability, financial market, and equity requirements. Another important area is the coverage of development risks through public risk-sharing. Research on public "insurance" has, thus far, focused on distributive issues and not so much on the coverage and prevention of development risks and industrial hazards.

Another interesting subject is the applicability of mutual risk-sharing. The oil accident case is an interesting, spontaneous development. Coastal states, i.e. the victims, were able to agree that the clean-up should be covered by the injurer. The law, including guarantee requirements and fees for clean-up, was able to be implemented by the power to exclude tankers from the harbours. Nonetheless, this coverage is insufficient for accidents of the Exxon Valdez. Therefore, the ability to pay needs to be increased. One way is to increase the required guarantee. Another is to raise the fee to fund future clean-ups. A third way to increase the applicability of industrial liability is to increase required solvency type. Effically, an important task of international organisations such as the UN and the EU is to limit random victimisation through new and more far-reaching conventions on liability and mutual guarantees.

${ }^{41}$ Exceptions are Kuntzman (1985), Holderness (1990), and Skogh (1991). 


\section{REFERENCES}

BENSON, G. J. and SMITH, CLIFFORD, W. Jr. (1976), "A Transactions Costs Approach to the Theory of Financial Intermediation", Journal of Finance, pp. 215-231.

BERLINER, B.(1982), Limits of Insurability of Risks, Prentice-Hall, Englewood Cliffs.

BONGAERTS, J and DE BIEVRE A. (1987), "Insurance for Civil Liability for Marine Oil Pollution Damages", The Geneva Paper of Risk and Insurance, Vol. 12, No. 43, pp. 145-157.

BORCH, K. (1990), Economics of Insurance, North Holland.

BUCHT, O. (1936), Försäkringsväsendets företagsformer från antiken till våra dagar, Kooperativa förbundets bokförlag, Stockholm.

ELTON, E.J and GRUBER, M.J., Modern Portfolio Theory and Investment Analysis, Second edition, John Wiley, New York.

FAURE, M. and VAN DEN BERGH, R. (1990), "Liability for nuclear accidents in Belgium from an interest group perspective", International Review of Law and Economics, pp. 241-254.

FAURE, M. and SKOGH, G. (1992), "Compensation for Damages Caused by Nuclear Accidents: A Convention as Insurance", Geneva Papers on Risk and Insurance, Vol. 17, No. 65, pp. 499-513.

GÄRDENFORS, P. and SAHLIN N-E. ed. (1988), Decision, Probability and Utility. Selected readings, Cambridge University Press.

HIRSCHHLEIFER, J. and RILEY J.G. (1979), "The Analytics of Uncertainty and Information -- An Expository Survey", Journal of Economic Literature, Vol. XVII No. 41: 375-1421.

HOGARTH, R.M. and KUNREUTHER, H. (1992), "Pricing Insurance and Warranties: Ambiguity and Correlated Risks", The Geneva Papers on Risk and Insurance Theory, No. 1.

HOLDERNESS, CLIFFORD G. (1990), "Liability Insurers as Corporate Monitors", 10, International Review of Law and Economics, pp. 115-129.

HÄGG, G. (1994), "The Economics of Trust, Trust Sensitive Contracts, and Regulation", International Review of Law and Economics, No 4.

KNIGHT, F. H. (1921), Risk, Uncertainty and Profit; Houghton Mifflin Company, Boston and New York.

KUNZMAN, STEVEN A. (1985), "The Insurer as Surrogate Regulator of the Hazardous Waste Industry: Solution or Perversion", 20, Forum, pp. 169-188.

KYBURG, H.R. "Bets and Beliefs", American Philosophical Quarterly, No. 5, pp. 63-78.

MAIN, B.G. (1982), "Business Insurance and Large, Widely-held Corporations", The Geneva Papers on Risk and Insurance, pp. 237-247.

MAIN, B.G. (1983), "Why Large Corporations Purchase Property/Liability Insurance", California Management Review, Vol. XXV, No. 2, pp. 84-95.

MAYERS, D. \& SMITH, Jr., C. W (1981), "Contractual Provisions, Organizational Structure, and Conflict Control in Insurance Markets", Journal of Business, Vol. 54, No. 3, pp. 407-34.

MAYERS, D. \& SMITH, Jr., C.W. (1982), "On the Corporate Demand for Insurance", Journal of Business, Vol. 55, No. 2, pp. 281-95.

MAYERS, D. \& SMITH, Jr., C.W. (1987), "Corporate Insurance and the Underinvestment Problem", The Journal of Risk and Insurance, 1: 45-54.

RAWLS, J., A Theory of Justice, Harvard University Press, Cambridge 
ROTHSHILD, M. and J. E. (1976), "Equilibrium in Competitive Insurance Markets: An Essay on the Economics of Imperfect Information", Quarterly Journal of Economics, 90, pp. 629-649.

SAVAGE, L.J. (1954), The Foundation of Statistics, John Wiley, New York.

SHAVELL, S. (1979), "On Moral Hazard and Insurance”, Quarterly Journal of Economics, No. 93, pp. 541-562.

SHAVELL, S (1986), "The Judgement Proof Problem", The International Review of Law and Economics, pp. 45-58.

SHAVELL, S. (1987), An Economic Analysis of Accident Law, Harvard University Press.

SKOGH, G. (1982), "Public Insurance and Accident Prevention", International Review of Law and Economics, pp. 67-80

SKOGH, G. (1989), "The Transactions Costs of Insurance: Contracting Impediments and Costs", The Journal of Risk and Insurance, pp. 726-732.

SKOGH, G. (1991), "Insurance and the Institutional Economics of Financial Intermediation", Geneva Papers on Risk and Insurance, pp. 360-370.

SKOGH, Göran (1996), Uncertainty, Risk-sharing and the Evolution of Insurance, Unpublished manuscript, Department of Economics, Lund University.

SKOGH, Göran (1997), Insurance and Liability, Unpublished manuscript, Department of Economics, Lund University.

SMITH, Jr., C.W. \& WARNER, J.B. (1979), "On Financial Contracting. An Analysis of Bond Covenants", Journal of Financial Economics, pp. 117-61.

SYKES, A. O. (1984), "The Economics of Vicarious Liability", The Yale Law Journal, Vol. 93: 1197, pp. 1231-1280.

TIETENBERG, T. (1989), "Indivisible Toxic Torts: The Economics of Joint and Several Liability", Land Economics, 65, pp. 305-319.

TYRAN, J-R. and ZWEIFEL, P. (1993), "Environmental Risk Internalization through Capital Markets (ERICAM): The case of Nuclear Power", International Review of Law and Economics, 13: 431-444.

WILLIAMSOM, O. E (1985), The Economic Institutions of Capitalism, Macmillan, New York. 